\title{
Isotherm Analysis on the Removal of Ni (II) ION from Wastewater using APANC
}

\author{
S Arivoli", A Arasakumar \\ PG and Research Department of Chemistry, Thiru Vi Ka Government Arts College, Thiruvarur, \\ Tamilnadu, India.
}

\begin{abstract}
Nickel plays an important role in metallurgical, electroplating and other chemical industries. About $40 \%$ of the nickel produced is used in steel factories, nickel batteries and in the production of some alloys. On the other hand, it may pollute aqueous streams, arising therefore several environmental problems. An adsorbent prepared from Pandanus Amaryllifolius Stem Ash, by acid treatment was tested for its efficiency in removing nickel ion. The process parameters studied include agitation time, initial Nickel ion concentration, adsorbent dose, $\mathrm{pH}$ and temperature. The adsorption followed second order reaction equation and the rate is mainly controlled by intra-particle diffusion. The equilibrium adsorption data were correlated with Langmuir, Freundlich, Temkin, Dubinin-Radushkevich, Hurkins-Jura, Halsay, Radlich-Peterson, Jovanovic and BET isotherm models. The adsorption capacity $\left(Q_{m}\right)$ obtained from the Langmuir isotherm plot at an initial pH of 6.5 and at 30,40, 50, $60 \pm 0.5^{\circ} \mathrm{C}$. The influence of $\mathrm{pH}$ on metal ion removal was significant and the adsorption was increased with increase in temperature. A portion of the nickel ion was recovered from the spent APANC using $0.1 \mathrm{M} \mathrm{HCl}$.
\end{abstract}

Keywords: Activated Pandanus Amaryllifolius Stem Nano Carbon (APANC), Nickel ion, Adsorption isotherm, Equilibrium, Thermodynamic parameters, Intra-particle diffusion.

\section{INTRODUCTION}

Heavy metal pollution of water and water bodies is a serious environmental problem that affects the quality of water. The consequences are decreasing water supply, increase in cost of purification, eutrophication of water bodies and decrease in aquatic production [1]. In order to tackle the menace poise by heavy metal pollution of water, several options have been adopted. These include oxidation and reduction, chemical precipitation, filtration, electrochemical treatment, ion exchange, membrane separation, reverse osmosis, adsorption, evaporation and electrolysis [2]. However, adsorption has been proven to be one of the best options available for the removal of heavy metals from aqueous solution $[3,4]$. In view of the above, several researches have been conducted using various materials as adsorbents [5-7]. However, some of these adsorbents also contain other toxicants; some are expensive and are characterized with limited surface area for adsorption.

A search of literature revealed that fruit stone has been used for adsorption of some heavy metals from aqueous solution but literature is scanty on the use of activated carbon produced from fruit stone for the adsorption of $\mathrm{Ni}$ (II) ions from aqueous solution. Therefore, the objective of the present study is to investigate the possibility of using APANC.

\section{MATERIALS AND MethodS}

\subsection{Adsorbent}

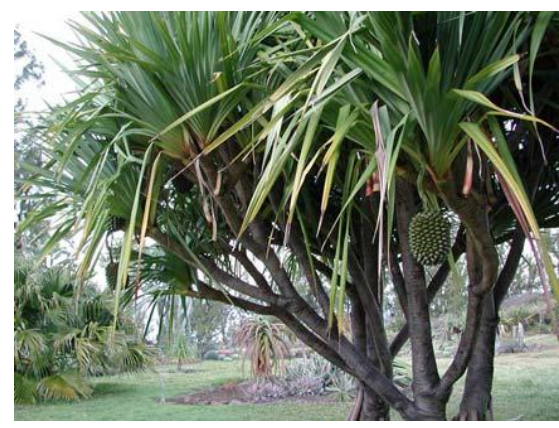

Pandanus Amaryllifolius Stem 
The Pandanus Amaryllifolius Stem collected from nearby Thiruvarur district was Carbonized with concentrated Sulphuric Acid and washed with water and activated around $1100^{\circ} \mathrm{C}$ in a muffle furnace for $5 \mathrm{hrs}$ the it was taken out, ground well to fine powder and stored in a vacuum desiccators.

\subsection{Chemicals}

All chemicals used of high purity commercially available Analar grade. $1000 \mathrm{mg} / \mathrm{L}$ of stock solution of nickel was prepared by dissolving accurately weighed 4.4786 gram of nickel sulphate in $1000 \mathrm{ml}$ distilled water. All experimental solutions were prepared by diluting the stock solution to the required concentration. The $\mathrm{pH}$ of each experimental solution was adjusted to the required initial $\mathrm{pH}$ value using dilute $\mathrm{HCl}$ (or) $\mathrm{NaOH}$ before mixing the adsorbent. The concentration of residual nickel ion was determined with atomic absorption spectrophotometer (Perkin Elemer 2380).

\subsection{Batch Experiments}

The effect of various parameters on the removal of nickel ion onto APANC was studied batch adsorption experiments were conducted at $\left(30-60^{\circ} \mathrm{C}\right)$. For each experimental run, $50 \mathrm{ml}$ of nickel solution of known initial concentration and $\mathrm{pH}$ were taken in a $250 \mathrm{ml}$ plugged conical flask. A $25 \mathrm{mg}$ adsorbent dose is added to the solution and mixture was shaken at constant agitation speed (150 rpm) sample were withdrawn at appropriate time intervals $(10-60 \mathrm{~min})$ and the adsorbent was separated by filtration. The residual solutions were analyzed to determine the nickel ion concentration.

The effect of dosage of adsorbent on the removal of nickel ion was measured by contacting $50 \mathrm{ml}$ of $50 \mathrm{mg} / \mathrm{L}$ of nickel ion solution with $25 \mathrm{mg}$ of APANC till equilibrium was attained. Adsorption equilibrium isotherm is studied using $25 \mathrm{mg}$ of APANC dosage per $50 \mathrm{ml}$ of nickel ion solution. The initial concentration were ranged from $(10$ to $50 \mathrm{mg} / \mathrm{L})$ in all sets of experiments. The plugged conical flask was shaken at a speed of $150 \mathrm{rpm}$ for 60 minutes. Then the solution was separated from the mixture and analyzed for nickel ion concentration. The adsorption capacity was calculated by using a mass equilibrium equation as follows:

$\mathrm{q}_{\mathrm{e}}=\left(\mathrm{C}_{0}-\mathrm{C}_{\mathrm{e}}\right) \mathrm{V} / \mathrm{M}$

Where $\mathrm{C}_{0}$ and $\mathrm{C}_{\mathrm{e}}$ being the initial nickel concentration $(\mathrm{mg} / \mathrm{L})$ and equilibrium concentration, respectively $\mathrm{V}$ is the experimental volume of nickel ion solution expressed in liters $[\mathrm{L}]$ and $\mathrm{M}$ is the adsorbent mass expressed in grams $[\mathrm{g}]$. The nickel ion ions percentage can be calculated as follows:

$\% \mathrm{R}=\left(\mathrm{C}_{0}-\mathrm{C}_{\mathrm{t}}\right) \times 100 / \mathrm{C}_{0}$

The effect of $\mathrm{pH}$ on the rate of adsorption was investigated using nickel concentration of $20 \mathrm{mg} / \mathrm{L}$ constant APANC dosage. The $\mathrm{pH}$ values were adjusted with dilute $\mathrm{HCl}$ and $\mathrm{NaOH}$ solution. The adsorbent-adsorbate mixture was shaken at room temperature using agitation speed $(150 \mathrm{rpm})$ for 60 minutes. Then the concentration of nickel in solution was determined.

\section{RESULTS AND DISCUSSION}

\subsection{Effect of Agitation Time and Initial Nickel Ion Concentration}

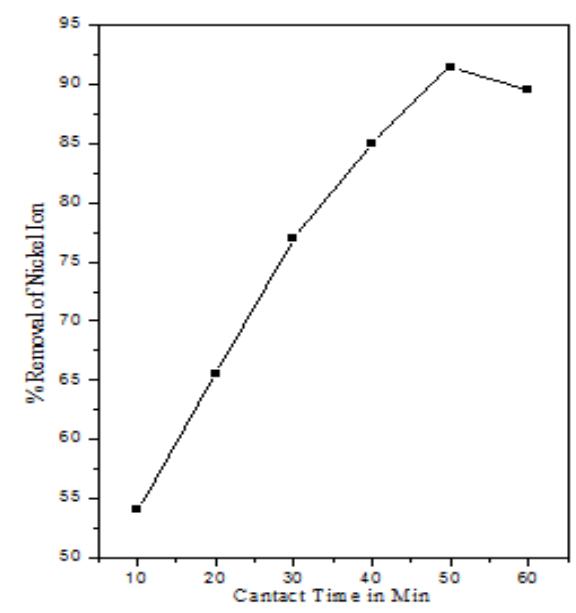

Fig1. Effect of Contact Time on the Removal of Nickel I on $[\mathrm{Ni}]=50 \mathrm{mg} / \mathrm{L}$; Temperature $30^{\circ} \mathrm{C}$; Adsorbent $d o_{s e}=25 \mathrm{mg} / 50 \mathrm{ml}$ 
The kinetics of adsorption of nickel ion by APANC is shown in (fig. 1) with smooth and single plots indicating monolayer adsorption of metal ion on the APANC. The removal of metal ion increased with the lapse time and attains equilibrium in $60 \mathrm{~min}$ for $50 \mathrm{mg} / \mathrm{L}$. With increase in metal ion concentration from 10 to $50 \mathrm{mg} / \mathrm{L}$, the amount of metal ion adsorbed increased while the percent removal decreased, indicating that the metal ion removal by adsorption on APANC concentration dependent.

\subsection{Effect of APANC Mass}

The amount of nickel ion adsorption increased with the increase in APANC dose and reached a maximum value after a particular dose (fig.2). Taken an initial metal ion concentration of $20 \mathrm{mg} / \mathrm{L}$, complete metal ion removal was obtained at a maximum APANC dose of $125 \mathrm{mg}$. The increase in the adsorption of metal ion with APANC dose was due to the introduction of more binding sites for adsorption and the availability more surface area.

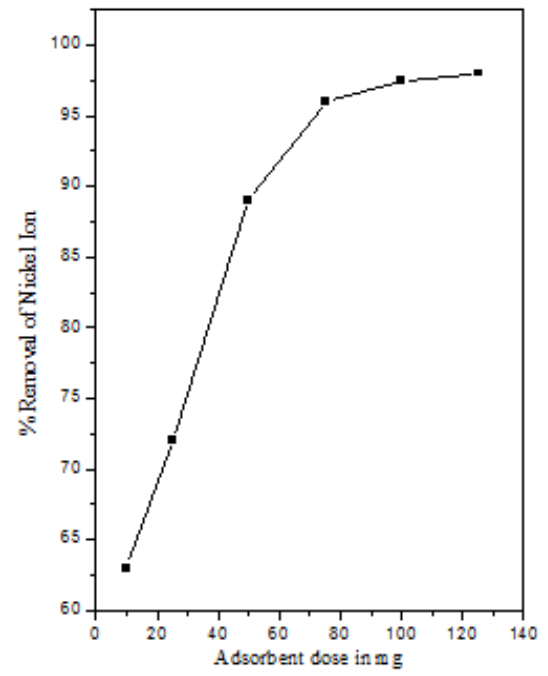

Fig2. Effect of Adsorbent dose on the removal of $\mathrm{Ni}$ Ion $[\mathrm{Ni}]=50 \mathrm{mg} / \mathrm{L}$; Contact Time 60m in; Temperature $30^{\circ} \mathrm{C}$

\subsection{Effect of $\mathbf{p H}$}

The experience carried out at different $\mathrm{pH}$ show that there was a change in the percent removal of metal ion over the entire $\mathrm{pH}$ range shown in Fig. 3. This indicates the strong force of interaction between the metal ion and APANC that either $\mathrm{H}^{+}$or $\mathrm{OH}^{-}$ions could influence the adsorption capacity. In other words, the adsorption of metal ion on APANC does involve ion exchange mechanism that have been an influence on the metal ion adsorption while varying the $\mathrm{pH}$ This observation is in line with the type I and II isotherm and positive $\Delta \mathrm{H}^{0}$ value obtained, which indicates irreversible adsorption probably due to polar interactions.

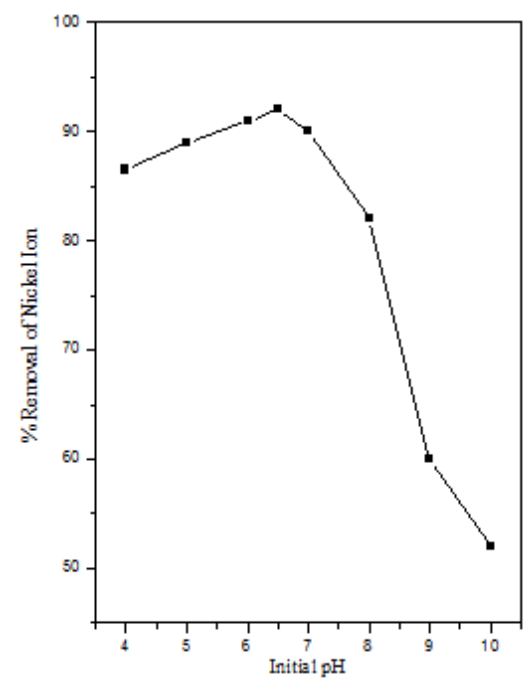

Fig3. Effect of Initial $\mathrm{pH}$ on the removal of $\mathrm{Ni}$ Ion $[\mathrm{Ni}]=50 \mathrm{mg} / \mathrm{L}$; Temperature $30 \mathrm{oC}$; Adsorbent dose= $25 \mathrm{mg} / 50 \mathrm{ml}$ 


\subsection{Effect of Other Ions}

The effect of other ions like $\mathrm{Ca}^{2+}$ and $\mathrm{Cl}^{-}$on the adsorption process studied at different concentrations. The ions added to $50 \mathrm{mg} / \mathrm{L}$ of metal ion solutions and the contents were agitated for $60 \mathrm{~min}$ at $30^{\circ} \mathrm{C}$. The results had shown in the Fig. 4 reveals that low concentration of $\mathrm{Cl}^{-}$does not affect the percentage of adsorption of metal ion on APANC, because the interaction of $\mathrm{Cl}^{-}$at available sites of adsorbent through competitive adsorption is not so effective. While the concentration of other ion $\mathrm{Ca}^{2+}$ increases, the interference of these ions at available surface sites of the sorbent through competitive adsorption increases that, decreases the percentage adsorption. The interference was more in the presence of $\mathrm{Ca}^{2+}$ compared with $\mathrm{Cl}^{-}$ion. This is so because ions with smaller hydrated radii decrease the swelling pressure within the sorbent and increase the affinity of the sorbent for such ions.

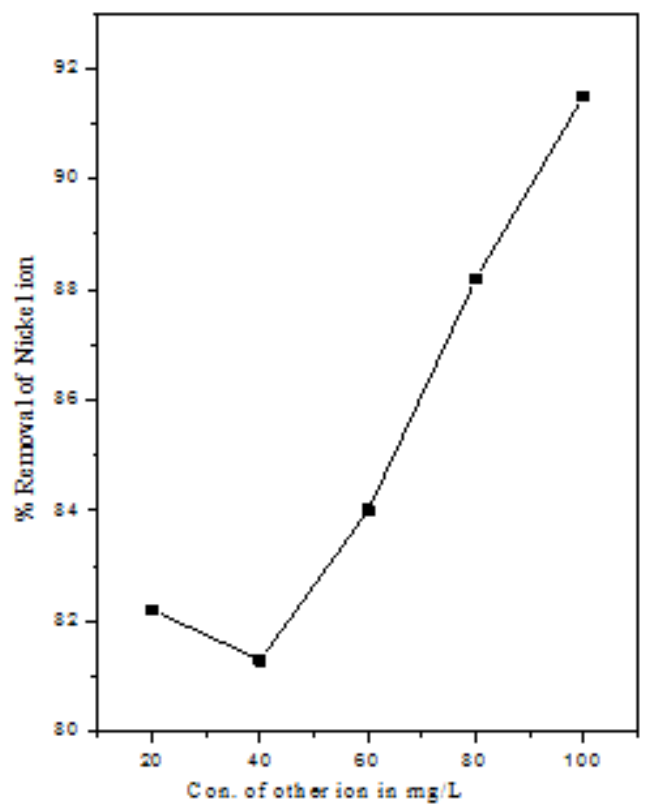

Fig4. Effect of ionic strength on the adsorption of Nickel ion $[\mathrm{Ni}]=50 \mathrm{mg} / \mathrm{L} ; \mathrm{pH}=6.5 ; \mathrm{Dose}=25 \mathrm{mg} / 50 \mathrm{ml}$

\subsection{Adsorption Isotherms}

Adsorption isotherm ${ }^{4-8}$ describes the relation between the amount or concentration of adsorbate that accumulates on the adsorbent and the equilibrium concentration of the dissolved adsorbate. Equilibrium studies were carried out by agitating a series of beakers containing $50 \mathrm{~mL}$ of $\mathrm{Ni}$ (II) solutions of initial concentration $20 \mathrm{mg} / \mathrm{L}$ with $0.025 \mathrm{~g}$ of activated nano carbon at $30{ }^{\circ} \mathrm{C}$ with a constant agitation. Agitation was provided for $1.0 \mathrm{~h}$, which is more than sufficient time to reach equilibrium.

\subsubsection{Freundlich Adsorption Isotherm}

The Freundlich adsorption isotherm is based on the equilibrium sorption on heterogeneous surfaces. This isotherm is derived from the assumption that the adsorption sites are distributed exponentially with respect to heat of adsorption. The adsorption isotherm is expressed by the following equation

$\mathrm{q}_{\mathrm{e}}=\mathrm{K}_{\mathrm{F}} \mathrm{C}_{\mathrm{e}}^{1 / \mathrm{nF}}$

Which, can be linearized as

$\ln \mathrm{q}_{\mathrm{e}}=\ln \mathrm{K}_{\mathrm{F}}+\frac{1}{\mathrm{n}_{\mathrm{F}}} \ln \mathrm{C}$

Where, $\mathrm{q}_{\mathrm{e}}$ is the amount of $\mathrm{Ni}$ (II) adsorbed at equilibrium $\left(\mathrm{mg} / \mathrm{g}\right.$ ) and $\mathrm{C}_{\mathrm{e}}$ is the concentration of $\mathrm{Ni}$ (II) in the aqueous phase at equilibrium ( $\mathrm{ppm}) . \mathrm{K}_{\mathrm{F}}(\mathrm{L} / \mathrm{g})$ and $1 / \mathrm{n}_{\mathrm{F}}$ are the Freundlich constants related to adsorption capacity and sorption intensity, respectively.

The Freundlich constants $\mathrm{K}_{\mathrm{F}}$ and $1 / \mathrm{n}_{\mathrm{F}}$ were calculated from the slope and intercept of the $\operatorname{lnq}_{\mathrm{e}} \mathrm{Vs}_{\mathrm{s}} \ln \mathrm{C}_{\mathrm{e}}$ plot, the model parameters are shown in Table 2. The magnitude of $\mathrm{K}_{\mathrm{F}}$ showed that APANC had a 
high capacity for $\mathrm{Ni}(\mathrm{II})$ adsorption from the aqueous solutions studied. The Freundlich exponent, $\mathrm{n}_{\mathrm{F}}$, should have values in the range of 1 and 10 (i.e., $1 / \mathrm{n}_{\mathrm{F}}<1$ ) to be considered as favourable adsorption'. A $1 / n_{F}$ value of less than 1 indicated that $\mathrm{Ni}(\mathrm{II})$ is favorably adsorbed by APANC. The Freundlich isotherm did not show a good fit to the experimental data as indicated by SSE and Chi-square statistics.

Table1. Equilibrium Parameters for the Adsorption of Nickel Ion onto APANC

\begin{tabular}{|c|c|c|c|c|c|c|c|c|c|c|c|c|}
\hline \multirow[t]{2}{*}{ M0 } & \multicolumn{4}{|c|}{$\mathrm{Ce}(\mathrm{Mg} / \mathrm{L})$} & \multicolumn{4}{|c|}{ Qe $(\mathrm{Mg} / \mathrm{L})$} & \multicolumn{4}{|c|}{ Removal \% } \\
\hline & $30^{\circ} \mathrm{C}$ & $40^{\circ} \mathrm{C}$ & $5^{\circ}{ }^{\circ} \mathrm{C}$ & $60^{\circ} \mathrm{C}$ & $30^{\circ} \mathrm{C}$ & $40^{\circ} \mathrm{C}$ & $50^{\circ} \mathrm{C}$ & $60^{\circ} \mathrm{C}$ & $3^{\circ} \mathrm{C}$ & $40^{\circ} \mathrm{C}$ & $\mathbf{5 0}^{\circ} \mathrm{C}$ & $60^{\circ} \mathrm{C}$ \\
\hline 25 & 3.80 & 3.63 & 3.73 & 3.00 & 92.39 & 92.72 & 92.53 & 93.98 & 92.39 & 92.72 & 92.53 & 93.98 \\
\hline 50 & 14.26 & 12.36 & 10.73 & 9.08 & 171.47 & 175.27 & 178.53 & 181.83 & 85.73 & 87.63 & 89.26 & 90.91 \\
\hline 75 & 30.36 & 27.64 & 23.09 & 20.68 & 239.26 & 244.70 & 253.80 & 258.62 & 79.75 & 81.56 & 84.60 & 86.20 \\
\hline 100 & 58.62 & 54.09 & 23.09 & 44.70 & 282.74 & 291.81 & 353.80 & 310.58 & 70.68 & 72.95 & 88.45 & 77.64 \\
\hline 125 & 90.67 & $\begin{array}{l}85.68 \\
\end{array}$ & 49.06 & 74.68 & 318.65 & 328.62 & 401.87 & 350.63 & 63.73 & 65.72 & 80.37 & 70.12 \\
\hline
\end{tabular}

Table2. Langmuir and Freundlich Isotherm Parameter for the Adsorption of Nickel Ion onto APANC

\begin{tabular}{|c|c|c|c|c|}
\hline \multirow{2}{*}{ Temp. (oC) } & \multicolumn{3}{|c|}{ Langmuir Parameters } & \multicolumn{2}{c|}{ Freundlich Parameters } \\
\cline { 2 - 5 } & $\mathbf{Q}_{\mathbf{m}}$ & $\mathrm{b}$ & $\mathbf{K}_{\mathbf{f}}$ & $\mathbf{n}$ \\
\hline $\mathbf{3 0}^{\circ} \mathbf{C}$ & 361.73 & 0.0703 & 1.7603 & $\mathbf{2 . 5 4 1 1}$ \\
\hline $\mathbf{4 0}^{\circ} \mathbf{C}$ & 373.39 & 0.0753 & 1.7743 & $\mathbf{2 . 4 9 4 9}$ \\
\hline $\mathbf{5 0}^{\mathbf{0}} \mathbf{C}$ & 574.08 & 0.0464 & 1.6440 & $\mathbf{1 . 6 9 3 2}$ \\
\hline $\mathbf{6 0}^{\circ} \mathbf{C}$ & $\mathbf{3 9 5 . 6 8}$ & $\mathbf{0 . 0 9 4 0}$ & $\mathbf{1 . 8 2 7 8}$ & $\mathbf{2 . 4 6 7 3}$ \\
\hline
\end{tabular}

\subsubsection{Langmuir Adsorption Isotherm}

The Langmuir adsorption isotherm is based on the assumption that all sorption sites possess equal affinity to the adsorbate. The Langmuir isotherm ${ }^{10}$ in a linear form can be represented as:

$$
\frac{C_{e}}{q_{e}}=\frac{1}{q_{m} K_{L}}+\frac{C_{e}}{q_{m}}
$$

Where $\mathrm{q}_{\mathrm{e}}$ is the amount of $\mathrm{Ni}(\mathrm{II})$ adsorbed at equilibrium $(\mathrm{mg} / \mathrm{g}), \mathrm{C}_{\mathrm{e}}$ is the concentration of $\mathrm{Ni}$ (II) in the aqueous phase at equilibrium (ppm), $\mathrm{q}_{\mathrm{m}}$ is the maximum $\mathrm{Ni}(\mathrm{II})$ uptake $(\mathrm{mg} / \mathrm{g})$, and $\mathrm{K}_{\mathrm{L}}$ is the Langmuir constant related to adsorption capacity and the energy of adsorption $(\mathrm{g} / \mathrm{mg})$.

A linear plot of $\mathrm{C}_{\mathrm{e}} / \mathrm{q}_{\mathrm{e}} \mathrm{Vs}_{\mathrm{e}} \mathrm{C}_{\mathrm{e}}$ was employed to determine the value of $\mathrm{q}_{\mathrm{m}}$ and $\mathrm{K}_{\mathrm{L}}$, the data so obtained were also presented in Table 2 . The model predicted a maximum value that could not be reached in the experiments. The value of $\mathrm{K}_{\mathrm{L}}$ decreased with an increase in the temperature. A high $\mathrm{K}_{\mathrm{L}}$ value indicates a high adsorption affinity. Weber and Chakraborti expressed the Langmuir isotherm in term of dimensionless constant separation factor or equilibrium parameter $\left(\mathrm{R}_{\mathrm{L}}\right)$ defined in the following equation:

$$
\mathrm{R}_{\mathrm{L}}=\frac{1}{1+\mathrm{K}_{\mathrm{L}} \mathrm{C}_{0}}
$$

Where, $\mathrm{C}_{0}$ is the initial $\mathrm{Ni}(\mathrm{II})$ concentration (ppm). Four scenarios can be distinguished:

The sorption isotherm is unfavorable when $R_{L}>1$, the isotherm is linear when $R_{L}=1$, The isotherm is favorable when $0<R_{L}<1$ and the isotherm is irreversible when $R_{L}=0$. The values of dimensionless separation factor $\left(\mathrm{R}_{\mathrm{L}}\right)$ for $\mathrm{Ni}(\mathrm{II})$ removal were calculated at different concentrations and temperatures. As shown in Table 3, at all concentrations and temperatures tested the values of $\mathrm{R}_{\mathrm{L}}$ for $\mathrm{Ni}$ (II) adsorptions on the APANC were less than 1 and greater than zero, indicating favorable adsorption.

The Langmuir isotherm showed a better fit to the adsorption data than the Freundlich isotherm. The fact that the Langmuir isotherm fits the experimental data well may be due to homogeneous distribution of active sites on the APANC surface, since the Langmuir equation assumes that the adsorbent surface is energetically homogeneous. 
Table3. Dimensionless Seperation Factor $\left(R_{l}\right)$ for the Adsorption of Nickel Ion onto APANC

\begin{tabular}{|c|c|c|c|c|}
\hline \multirow{2}{*}{$(\mathbf{C i})$} & \multicolumn{3}{|c|}{ Temperature $^{\circ} \mathbf{C}$} & $\mathbf{6 0}^{\mathbf{0}} \mathbf{C}$ \\
\cline { 2 - 5 } & $\mathbf{3 0}^{\mathbf{0}} \mathbf{C}$ & $\mathbf{4 0}^{\mathbf{}} \mathbf{C}$ & 0.3011 & $\mathbf{0 . 1 7 5 3}$ \\
\hline $\mathbf{2 5}$ & 0.2214 & 0.2096 & 0.1772 & $\mathbf{0 . 0 9 6 0}$ \\
\hline $\mathbf{5 0}$ & 0.1244 & 0.1171 & 0.1256 & $\mathbf{0 . 0 6 6 1}$ \\
\hline $\mathbf{7 5}$ & 0.0865 & 0.0812 & 0.0972 & $\mathbf{0 . 0 5 0 4}$ \\
\hline $\mathbf{1 0 0}$ & 0.0663 & 0.0621 & $\mathbf{0 . 0 7 9 3}$ & $\mathbf{0 . 0 4 0 7}$ \\
\hline $\mathbf{1 2 5}$ & $\mathbf{0 . 0 5 3 8}$ & $\mathbf{0 . 0 5 0 3}$ &
\end{tabular}

\subsubsection{Temkin Adsorption Isotherm}

The Temkin adsorption isotherm assumes that the heat of adsorption decreases linearly with the sorption coverage due to adsorbent-adsorbate interactions ${ }^{11}$ The Temkin isotherm equation is given as:

$$
\mathrm{q}_{\mathrm{e}}=\frac{\mathrm{RT}}{\mathrm{bT}} \ln \left(\mathrm{K}_{\mathrm{T}} \mathrm{C}_{\mathrm{e}}\right)
$$

Which, can be represented in the following linear form

$$
\mathrm{q}_{\mathrm{e}}=\frac{\mathrm{RT}}{\mathrm{b}} \ln \mathrm{K}_{\mathrm{T}}+\frac{\mathrm{RT}}{\mathrm{b}} \ln \mathrm{C}_{\mathrm{e}}
$$

Where, $\mathrm{K}_{\mathrm{T}}(\mathrm{L} / \mathrm{g})$ is the Temkin isotherm constant, $\mathrm{b}_{\mathrm{T}}(\mathrm{J} / \mathrm{mol})$ is a constant related to heat of sorption, $\mathrm{R}$ is the ideal gas constant $(8.314 \mathrm{~J} / \mathrm{mol} \mathrm{K})$, and $\mathrm{T}$ is absolute temperature $(\mathrm{K})$. A plot of $\mathrm{q}_{\mathrm{e}}$ versus $\operatorname{lnC}_{\mathrm{e}}$ enables the determination of isotherm constants $\mathrm{K}_{\mathrm{T}}$ and $\mathrm{b}_{\mathrm{T}}$ from the slope and intercept, The model parameters are listed in Table 2. The Temkin isotherm appears to provide a good fit to the $\mathrm{Ni}$ (II) adsorption data.

The adsorption energy in the Temkin model, $b_{\mathrm{T}}$, is positive for $\mathrm{Ni}(\mathrm{II})$ adsorption from the aqueous solution, which indicates that the adsorption is endothermic. The experimental equilibrium curve is close to that predicted by Temkin model. Consequently, the adsorption isotherm of Ni(II) on APANC can be described reasonably well by the Temkin isotherm.

\subsubsection{Hurkins-Jura Adsorption Isotherm}

The Hurkins-Jura ${ }^{12}$ adsorption isotherm can be expressed as:

$\mathrm{q}_{\mathrm{e}}=\sqrt{\frac{\mathrm{A}_{\mathrm{H}}}{\mathrm{B}_{\mathrm{H}}+\log \mathrm{C}_{\mathrm{e}}}}$

This can rearranged as follows:

$\frac{1}{\mathrm{q}_{\mathrm{e}}^{2}}=\frac{\mathrm{B}_{\mathrm{H}}}{\mathrm{A}_{\mathrm{H}}}-\frac{1}{\mathrm{~A}_{\mathrm{H}}} \log \mathrm{C}_{\mathrm{e}}$

Where, $A_{H}\left(g^{2} / L\right)$ and $B_{H}\left(\mathrm{mg}^{2} / L\right)$ are two parameters characterizing the sorption equilibrium.

The isotherm equation accounts for multilayer adsorption and can be explained by the existence of a heterogeneous pore distribution. The Harkins-Jura isotherm parameters are obtained from the plots of of $1 / \mathrm{q}_{\mathrm{e}}^{2}$ versus $\log \mathrm{C}_{\mathrm{e}}$ enables the determination of model parameters $\mathrm{A}_{\mathrm{H}}$ and $\mathrm{B}_{\mathrm{H}}$ from the slope and intercept.

\subsubsection{Halsay Adsorption Isotherm}

The Halsay ${ }^{13}$ adsorption isotherm can be given as

$\mathrm{q}_{\mathrm{e}}=\exp \left(\frac{\ln \mathrm{K}_{\mathrm{Ha}}-\ln \mathrm{C}_{\mathrm{e}}}{\mathrm{n}_{\mathrm{Ha}}}\right)$

And, a linear form of the isotherm can be expressed as follows:

$\operatorname{lnq}_{\mathrm{e}}=\frac{\operatorname{lnK} \mathrm{Ha}}{\mathrm{n}_{\mathrm{Ha}}}-\frac{\ln \mathrm{C}_{\mathrm{e}}}{\mathrm{n}_{\mathrm{Ha}}}$

Where, $\mathrm{K}_{\mathrm{Ha}}(\mathrm{mg} / \mathrm{L})$ and $\mathrm{n}_{\mathrm{Ha}}$ are the Halsay isotherm constants. 
A plot of $\operatorname{lnq} \mathrm{e}_{\mathrm{e}} \mathrm{Vs} \ln \mathrm{C}_{\mathrm{e}}$, enables the determination of $\mathrm{n}_{\mathrm{Ha}}$ and $\mathrm{K}_{\mathrm{Ha}}$ from the slope and intercept. This equation is suitable for multilayer adsorption and the fitting of the experimental data to this equation attest to the heteroporous nature of adsorbent. The experimental data and the model predictions based on the non-linear form of the Halsay models. The model parameters are listed in Table 2. This result also shows that the adsorption of $\mathrm{Ni}$ (II) on APANC was not based on significant multilayer adsorption. The Halsay model is also not suitable to describe the adsorption of Ni(II) on APANC, because this model also assumes a multilayer behavior for the adsorption of adsorbate onto adsorbent.

\subsubsection{Radlich-Peterson Adsorption Isotherm}

The Radlich-Peterson ${ }^{14}$ adsorption isotherm contains three parameters and incorporates the features of Langmuir and Freundlich isotherms into a single equation. The general isotherm equation can be described as follows:

$$
\mathrm{q}_{\mathrm{e}}=\frac{\mathrm{K}_{\mathrm{R}} \mathrm{C}_{\mathrm{e}}}{1+\mathrm{a}_{\mathrm{R}} \mathrm{C}_{\mathrm{e}}^{\mathrm{g}}}
$$

The linear form of the isotherm can be expressed as follows:

$\ln \frac{\mathrm{C}_{\mathrm{e}}}{\mathrm{q}_{\mathrm{e}}}=\mathrm{gln}_{\mathrm{e}}-\ln \mathrm{K}_{\mathrm{R}}$

Where, $\mathrm{K}_{\mathrm{R}}(\mathrm{L} / \mathrm{g})$ and $\mathrm{a}_{\mathrm{R}}(\mathrm{L} / \mathrm{mg})$ are the Radlich-Peterson isotherm constants and $\mathrm{g}$ is the exponent between 0 and 1 . There are two limiting cases: Langmuir form for $g=1$ and Henry's law for $g=0$.

A plot of $\ln \mathrm{C}_{\mathrm{e}} / \mathrm{q}_{\mathrm{e}}$ versus $\ln \mathrm{C}_{\mathrm{e}}$ enables the determination of isotherm constants $\mathrm{g}$ and $\mathrm{K}_{\mathrm{R}}$ from the slope and intercept. The values of $K_{R}$, presented in Table 2, indicate that the adsorption capacity of the APANC decreased with an increase temperature. Furthermore, the value of $g$ lies between 0 and 1 , indicating favorable adsorption.

\subsubsection{Dubinin-Radushkevich Adsorption Isotherm}

The Dubinin-Radushkevich ${ }^{15}$ adsorption isotherm is another isotherm equation [32]. It is assumed that the characteristic of the sorption curve is related to the porosity of the adsorbent. The linear form of the isotherm can be expressed as follows:

$$
\operatorname{lnq}_{\mathrm{e}}=\ln \mathrm{Q}_{\mathrm{D}}-\mathrm{B} \mathrm{D}\left[\mathrm{RT} \ln \left(1+\frac{1}{\mathrm{C}_{\mathrm{e}}}\right)\right]^{2}
$$

Where, $\mathrm{Q}_{\mathrm{D}}$ is the maximum sorption capacity $(\mathrm{mol} / \mathrm{g})$, and $\mathrm{B}_{\mathrm{D}}$ is the Dubinin-Radushkevich constant $\left(\mathrm{mol}^{2} / \mathrm{kJ}^{2}\right)$. A plot of $\operatorname{lnq}_{\mathrm{e}} \mathrm{Vs}_{\mathrm{T}} \ln \left(1+1 / \mathrm{C}_{\mathrm{e}}\right)$ enables the determination of isotherm constants $\mathrm{B}_{\mathrm{D}}$ and $\mathrm{Q}_{\mathrm{D}}$ from the slope and intercept.

\subsubsection{Jovanovic Adsorption Isotherm}

The model of an adsorption surface considered by Jovanovic ${ }^{16}$ is essentially the same as that considered by Langmuir. The Jovanovic model leads to the following relationship [29]:

$\mathrm{q}_{\mathrm{e}}=\mathrm{q}_{\max }\left(1-\mathrm{e}^{\mathrm{K}_{\mathrm{J}} \mathrm{C}_{\mathrm{e}}}\right)$

The linear form of the isotherm can be expressed as follows:

$$
\operatorname{lnq}_{\mathrm{e}}=\operatorname{lnq}_{\max }-\mathrm{K}_{\mathrm{J}} \mathrm{C}_{\mathrm{e}}
$$

Where, $\mathrm{K}_{\mathrm{J}}(\mathrm{L} / \mathrm{g})$ is a parameter. $\mathrm{q}_{\max }(\mathrm{mg} / \mathrm{g})$ is the maximum $\mathrm{Ni}(\mathrm{II})$ (II) uptake.

The $\mathrm{q}_{\max }$ is obtained from a plot of $\ln \mathrm{q}_{\mathrm{e}}$ and $\mathrm{C}_{\mathrm{e}}$, Their related parameters are listed in Table 2.

By comparing the values of the error functions, it was found the Langmuir and Temkin models are best to fit the Ni(II) adsorption on the AASCA. Both models show a high degree of correlation. Confirming the good fit of Langmuir and Temkin models with the experimental data for removal of $\mathrm{Ni}(\mathrm{II})$ from the solution.

\subsubsection{The Brunauer-Emmett-Teller (BET) Isotherm Model}

Brunauer-Emmett-Teller (BET) ${ }^{17}$ isotherm is a theoretical equation, most widely applied in the gassolid equilibrium systems. It was developed to derive multilayer adsorption systems with relative 
pressure ranges from 0.05 to 0.30 corresponding to a monolayer coverage lying between 0.50 and 1.50. Its extinction model related to liquid-solid interface is exhibited as:

$\mathrm{q}_{\mathrm{e}}=\frac{\mathrm{q}_{\mathrm{s}} \mathrm{C}_{\mathrm{BET}} \mathrm{C}_{\mathrm{e}}}{\left(\mathrm{C}_{\mathrm{S}}-\mathrm{C}_{\mathrm{e}}\right)\left[1+\left(\mathrm{C}_{\mathrm{BET}}-1\right)\left(\mathrm{C}_{\mathrm{e}} / \mathrm{C}_{\mathrm{S}}\right)\right]}$

Where, CBET, Cs, qs and qe are the BET adsorption isotherm $(\mathrm{L} / \mathrm{mg})$, adsorbate monolayer saturation concentration $(\mathrm{mg} / \mathrm{L})$, theoretical isotherm saturation capacity $(\mathrm{mg} / \mathrm{g})$ and equilibrium adsorption capacity $(\mathrm{mg} / \mathrm{g})$, respectively. As $\mathrm{C}_{\mathrm{BET}}$ and $\mathrm{C}_{\mathrm{BET}}\left(\mathrm{C}_{\mathrm{e}} / \mathrm{C}_{\mathrm{s}}\right)$ is much greater than 1 ,

In the linear form as used is represented as

$$
\frac{\mathrm{C}_{\mathrm{e}}}{\mathrm{q}\left(\mathrm{C}_{\mathrm{s}}-\mathrm{C}_{\mathrm{e}}\right)}=\frac{1}{\mathrm{q}_{\mathrm{s}} \mathrm{C}_{\mathrm{BET}}}+\left(\frac{\mathrm{C}_{\mathrm{BET}}-1}{\mathrm{q}_{\mathrm{s}} \mathrm{C}_{\mathrm{BET}}}\right)\left(\frac{\mathrm{C}_{\mathrm{e}}}{\mathrm{C}_{\mathrm{s}}}\right)
$$

Where, $\mathrm{C}_{\mathrm{e}}$ is equilibrium Concentration $(\mathrm{mg} / \mathrm{l}), \mathrm{C}_{\mathrm{s}}$ is adsorbate monolayer saturation concentration $(\mathrm{mg} / \mathrm{l})$ and $\mathrm{C}_{\mathrm{BET}}$ is BET adsorption relating to the energy of surface interaction $(1 / \mathrm{mg})$ the BET model.

\subsection{Kinetic Parameters}

The rate and mechanism of the adsorption process can be elucidated based on kinetic studies. Ni(II) adsorption on solid surface may be explained by two distinct mechanisms: (1) An initial rapid binding of Ni(II) molecules on the adsorbent surface; (2) relatively slow intra-particle diffusion. To analyze the adsorption kinetics of the $\mathrm{Ni}(\mathrm{II})$, the pseudo-first-order, the pseudo-second-order, and intraparticle diffusion models were applied ${ }^{18}$. Each of these models and their linear modes of them equations presented in below.

\begin{tabular}{|l|l|l|c|}
\hline \multicolumn{5}{|c|}{ Kinetic Models and Their Linear Forms } \\
\hline \multicolumn{1}{|c|}{ Model } & \multicolumn{1}{|c|}{ Nonlinear Form } & Linear Form & Number of Equation \\
\hline Pseudo-first-order & $\mathrm{dq}_{\mathrm{t}} / \mathrm{d}_{\mathrm{t}}=\mathrm{k}_{1}\left(\mathrm{q}_{\mathrm{e}}-\mathrm{q}_{\mathrm{t}}\right)$ & $\ln \left(\mathrm{q}_{\mathrm{e}}-\mathrm{q}_{\mathrm{t}}\right)=\ln \mathrm{q}_{\mathrm{e}}-\mathrm{k}_{\mathrm{t}} \mathrm{t}$ & $(20)$ \\
\hline Pseudo-second-order & $\mathrm{dq}_{\mathrm{t}} / \mathrm{d}_{\mathrm{t}}=\mathrm{k}_{2}\left(\mathrm{q}_{\mathrm{e}}-\mathrm{q}_{\mathrm{t}}\right)^{2}$ & $\mathrm{t} / \mathrm{q}_{\mathrm{t}}=1 / \mathrm{k}^{2} \mathrm{q}_{\mathrm{e}}{ }^{2}+\left(1 / \mathrm{q}_{\mathrm{e}}\right) \mathrm{t}$ & $(21)$ \\
\hline
\end{tabular}

Where, $\mathrm{q}_{\mathrm{e}}$ and $\mathrm{q}_{\mathrm{t}}$ refer to the amount of $\mathrm{Ni}$ (II) adsorbed $(\mathrm{mg} / \mathrm{g}$ ) at equilibrium and at any time, $\mathrm{t}(\mathrm{min})$, respectively and $\mathrm{k}_{1}(1 / \mathrm{min}), \mathrm{k}_{2}(\mathrm{~g} / \mathrm{mg}$.min) are the equilibrium rate constants of pseudo-first order and pseudo-second order models, respectively.

Pseudo-first order model is a simple kinetic model, which was proposed by Lagergren during 1898 and is used for estimation of the surface adsorption reaction rate. The values of $\ln \left(q_{e}-q_{t}\right)$ were linearly correlated with $t$. The plot of $\ln \left(\mathrm{q}_{\mathrm{e}}-\mathrm{q}_{\mathrm{t}}\right) \mathrm{Vs} \mathrm{t}$ should give a linear relationship from which the values of $\mathrm{k}_{1}$ were determined from the slope of the plot. In many cases, the first-order equation of Lagergren does not fit well with the entire range of contact time and is generally applicable over the initial stage of the adsorption processes.

In the pseudo-second order model, the slope and intercept of the $\mathrm{t} / \mathrm{qt} \mathrm{Vs} t$ plot were used to calculate the second-order rate constant, $\mathrm{k}_{2}$. The values of equilibrium rate constant $\left(\mathrm{k}_{2}\right)$ are presented in Table 5. According to Table 5, the value of $\mathrm{R}^{2}(0.999)$ related to the pseudo-second order model revealed that $\mathrm{Ni}$ (II) adsorption followed this model, which is in agreement with the results obtained by Karagoz et al. ${ }^{19}$ Hameed et al. ${ }^{20}$. Nevertheless, pseudo-first order and pseudo-second order kinetic models cannot identify the mechanism of diffusion of $\mathrm{Ni}(\mathrm{II})$ into the adsorbent pores.

\subsubsection{Simple Elovich Model}

The simple Elovich model ${ }^{21}$ is expressed in the form,

$\mathrm{q}_{\mathrm{t}}=\alpha+\beta \ln \mathrm{t}$

Where, $q_{t}$ is the amount adsorbed at time $t, \alpha$ and $\beta$ are the constants obtained from the experiment. A plot of $\mathrm{q}_{\mathrm{t}} \mathrm{Vs}$ lnt should give a linear relationship for the applicability of the simple Elovich kinetic. The Elovich kinetics of $\mathrm{Ni}(\mathrm{II})$ on to APANC for various initial concentrations (10, 20, 30, 40 and 50 $\mathrm{mg} / \mathrm{L}$ ) of volume $50 \mathrm{~mL}$ (each), adsorbent dose $0.025 \mathrm{~g}$, temperature $30{ }^{\circ} \mathrm{C}$ and $\mathrm{pH} 6.5$.

\subsubsection{The Elovich Equation}

The Elovich model equation is generally expressed as

$\mathrm{dq}_{\mathrm{t}} / \mathrm{d}_{\mathrm{t}}=\alpha \exp \left(-\beta \mathrm{q}_{\mathrm{t}}\right)$ 
Where; $\alpha$ is the initial adsorption rate $\left(\mathrm{mg} \mathrm{g}^{-1} \mathrm{~min}^{-1}\right)$ and $\beta$ is the desorption constant $(\mathrm{g} / \mathrm{mg})$ during any one experiment. To simplify the Elovich equation. Chien and Clayton (1980) assumed $\alpha \beta t>>t$ and by applying boundary conditions $\mathrm{q}_{\mathrm{t}}=0$ at $\mathrm{t}=0$ and $\mathrm{q}_{\mathrm{t}}=\mathrm{q}_{\mathrm{t}}$ at $\mathrm{t}=\mathrm{t}$ Eq.(23) becomes:

$\mathrm{q}_{\mathrm{t}}=1 / \beta \ln (\alpha \beta)+1 / \beta \ln \mathrm{t}$

If $\mathrm{Ni}$ (II) ions adsorption fits with the Elovich model, a plot of $\mathrm{q}_{\mathrm{t}} \mathrm{vs} \cdot \ln (\mathrm{t})$ should yield a linear relationship with a slope of $(1 / \beta)$ and an intercept of $(1 / \beta) \ln (\alpha \beta)$. The Elovich model parameters $\alpha, \beta$, and correlation coefficient $(\gamma)$ are summarized in table 5. The experimental data such as the initial adsorption rate $(\alpha)$ adsorption constant $(\beta)$ and the correlation co-efficient $(\gamma)$ calculated from this model indicates that the initial adsorption $(\alpha)$ increases with temperature similar to that of initial adsorption rate (h) in pseudo-second-order kinetics models. This may be due to increase the pore or active site on the APANC adsorbent.

\subsubsection{The Intraparticle Diffusion Model}

The kinetic results were analyzed by the Intraparticle diffusion $\operatorname{model}^{22}$ to elucidate the diffusion mechanism. The model is expressed as:

$\mathrm{q}_{\mathrm{t}}=\mathrm{K}_{\mathrm{id}} \mathrm{t}^{1 / 2}+\mathrm{I}$

Where, I is the intercept and $\mathrm{K}_{\text {id }}$ is the intra-particle diffusion rate constant. The intercept of the plot reflects the boundary layer effect. Larger the intercept, greater is the contribution of the surface sorption in the rate controlling step. The calculated diffusion coefficient $\mathrm{K}_{\mathrm{id}}$ values are listed in Table 6. The $K_{\text {id }}$ value was higher at the higher concentrations. Intraparticle diffusion is the sole ratelimiting step if the regression of $\mathrm{q}_{\mathrm{t}}$ versus $\mathrm{t}^{1 / 2}$ is linear and passes through the origin. In fact, the linear plots at each concentration did not pass through the origin. This deviation from the origin is due to the difference in the rate of mass transfer in the initial and final stages of the sorption. This indicated the existence of some boundary layer effect and further showed that Intraparticle diffusion was not the only rate-limiting step.

It is clear from the Table 6 that the pseudo- second-order kinetic model showed excellent linearity with high correlation coefficient $\left(\mathrm{R}^{2}>0.99\right)$ at all the studied concentrations in comparison to the other kinetic models. In addition the calculated $\mathrm{q}_{\mathrm{e}}$ values also agree with the experimental data in the case of pseudo-second-order kinetic model. It is also evident from Table 5 that the values of the rate constant $\mathrm{k}_{2}$ decrease with increasing initial $\mathrm{Ni}$ (II) concentrations. This is due to the lower competition for the surface active sites at lower concentration but at higher concentration the competition for the surface active sites will be high and consequently lower sorption rates are obtained.

\subsection{Thermodynamic Treatment of the Adsorption Process}

Thermodynamic parameters associated with the adsorption, via standard free energy change $\left(\Delta \mathrm{G}^{0}\right)$, standard enthalpy change $\left(\Delta \mathrm{H}^{0}\right)$, and standard entropy change $\left(\Delta \mathrm{S}^{0}\right)$ were calculated as follows. The free energy of adsorption process considering the adsorption equilibrium constant $\mathrm{K}_{0}$ is given by the equation

$$
\Delta \mathrm{G}^{\circ}=-\mathrm{RT} \ln \mathrm{K}_{0}
$$

Where, $\Delta \mathrm{G}^{\circ}$ is the free energy of adsorption $(\mathrm{kJ} / \mathrm{mol}), \mathrm{T}$ is the temperature in Kelvin and $\mathrm{R}$ is the universal gas constant $(8.314 \mathrm{~J} \mathrm{~mol} / \mathrm{K})$. The adsorption distribution coefficient $\mathrm{K}_{0}$ for the sorption reaction was determined from the slope of the plot of $\ln \left(\mathrm{q}_{\mathrm{e}} / \mathrm{C}_{\mathrm{e}}\right)$ against $\mathrm{C}_{\mathrm{e}}$ at different temperature and extrapolating to zero $C_{e}$ according to the method suggested by Khan and Singh[16] The adsorption distribution coefficient may be expressed in terms of enthalpy change $\left(\Delta \mathrm{H}^{\circ}\right)$ and entropy change $\left(\Delta \mathrm{S}^{\circ}\right)$ as a function of temperature,

$\ln \mathrm{K}_{\mathrm{o}}=\left(\Delta \mathrm{H}^{\mathrm{o}} / \mathrm{RT}\right)+\left(\Delta \mathrm{S}^{\mathrm{o}} / \mathrm{R}\right)$

Where, $\Delta \mathrm{H}^{\circ}$ is the standard heat change of sorption $(\mathrm{kJ} / \mathrm{mol})$ and $\Delta \mathrm{S}^{\circ}$ is standard entropy change (kJ/mol). The value of $\Delta \mathrm{H}^{\circ}$ and $\Delta \mathrm{S}^{\circ}$ can be obtained from the slope and intercept of plot of $\ln \mathrm{K}_{0}$ against $1 / \mathrm{T}$. The value of thermodynamic parameter calculated from equation 26 and 10 are shown in table 4 . The thermodynamic treatment of the sorption data indicates that $\Delta \mathrm{G}^{\circ}$ values were negative at all temperature. The results point out that physisorption is much more favorable for the adsorption of $\mathrm{Ni}$ (II) ions. The positive values of $\Delta \mathrm{H}^{\circ}$ show the endothermic nature of adsorption and it governs the 
possibility of physical adsorption [17]. Because in the case of physical adsorption, while increasing the temperature of the system, the extent of metal ion adsorption increases, this rules out the possibility of chemisorptions. The low $\Delta \mathrm{H}^{\circ}$ value depicts metal ion is physisorbed onto adsorbent APANC.

The negative $\Delta \mathrm{G}^{\circ}$ values table 4 were conform the spontaneous nature of adsorption Ni (II) ions onto APANC. The lesser values of $\Delta \mathrm{G}^{\circ}$ suggest that adsorption is physical adsorption process. The positive values of $\Delta \mathrm{S}^{\circ}$ in table 4 , showed increased randomness of the solid solution interface during the adsorption of nickel ion onto activated plasters Paris.

In order to support that physical adsorption is the predominant mechanism, the values of activation energy (Ea) and sticking probability $\left(\mathrm{S}^{*}\right)$ were calculated from the experimental data. They were calculated using modified Arrhenius type equation related to surface coverage $(\theta)$ as follows:

$$
\begin{aligned}
& \theta=\left(1-\frac{\mathrm{C}_{\mathrm{e}}}{\mathrm{C}_{\mathrm{i}}}\right) \\
& S^{*}=(1-\theta)_{e} \frac{-E_{a}}{R T}
\end{aligned}
$$

The sticking probability, $\mathrm{S}^{*}$, is a function of the adsorbate/adsorbent system under consideration but must satisfy the condition $0<\mathrm{S} *<1$ and is dependent on the temperature of the system. The values of Ea and $S^{*}$ can be calculated from slope and intercept of the plot of $\ln (1-\theta)$ versus $1 /$ T respectively (As shown in Fig. 17) and are listed in Table 4.

\begin{tabular}{|c|c|c|c|c|c|c|}
\hline \multirow[t]{2}{*}{ (CO) } & \multicolumn{4}{|c|}{$\Delta \mathbf{G o}$} & \multirow[t]{2}{*}{$\Delta \mathbf{H}^{\circ}$} & \multirow[t]{2}{*}{$\Delta \mathbf{S}^{\circ}$} \\
\hline & $30^{\circ} \mathrm{C}$ & $40^{\circ} \mathrm{C}$ & $50^{\circ} \mathrm{C}$ & $60^{\circ} \mathrm{C}$ & & \\
\hline 25 & -6289.62 & -6623.7 & -6759.89 & -7612.5 & 6.029 & 40.41 \\
\hline 50 & -4518.22 & -5096.11 & -5689.3 & -6377.31 & 14.15 & 61.56 \\
\hline 75 & -3453.76 & -3870.54 & -4575.28 & -5074.15 & 13.42 & 55.54 \\
\hline 100 & -2217.31 & -2582.12 & -5467.31 & -3447.26 & 18.39 & 68.61 \\
\hline 125 & -1420.07 & -1694.32 & -3786.12 & -2362.47 & 13.97 & 51.23 \\
\hline
\end{tabular}

Table4. Thermodynamic Parameter for the Adsorption of Nickel Ion onto APANC

\begin{tabular}{|c|c|c|c|c|c|c|c|c|c|c|c|}
\hline \multirow[t]{2}{*}{$\mathrm{CO}$} & \multirow{2}{*}{$\begin{array}{l}\text { Temp } \\
{ }^{\circ} \mathrm{C}\end{array}$} & \multicolumn{4}{|c|}{ Pseudo second order } & \multicolumn{3}{|c|}{ Elovich model } & \multicolumn{3}{|c|}{$\begin{array}{l}\text { Intraparticle } \\
\text { diffusion }\end{array}$} \\
\hline & & $\mathbf{q}_{\mathrm{e}}$ & $\mathbf{K}_{2}$ & $\gamma$ & $\mathbf{h}$ & $\alpha$ & $\beta$ & $\gamma$ & $\mathbf{K}_{\text {id }}$ & $\gamma$ & $\mathbf{C}$ \\
\hline \multirow[t]{4}{*}{25} & 30 & 102.15 & $21 \times 10^{-3}$ & 0.9952 & 14.01 & 134.90 & 0.0694 & 0.9959 & 1.6461 & 0.994 & 0.1771 \\
\hline & 40 & 100.41 & $19 \times 10^{-3}$ & 0.9983 & 16.28 & 427.67 & 0.0846 & 0.9968 & 1.7065 & 0.995 & 0.1416 \\
\hline & 50 & 99.85 & $18 \times 10^{-3}$ & 0.9960 & 17.75 & 744.47 & 0.0913 & 0.9982 & 1.7284 & 0.997 & 0.1298 \\
\hline & 60 & 101.59 & $17 \times 10^{-3}$ & 0.9940 & 17.50 & 401.61 & 0.0818 & 0.9948 & 1.7105 & 0.999 & 0.1446 \\
\hline \multirow[t]{4}{*}{50} & 30 & 188.47 & $25 \times 10^{-3}$ & 0.9946 & 26.66 & 297.98 & 0.0387 & 0.9961 & 1.6238 & 0.998 & 0.1705 \\
\hline & 40 & 192.25 & $24 \times 10^{-3}$ & 0.9988 & 27.23 & 353.65 & 0.0391 & 0.9987 & 1.6417 & 0.997 & 0.1647 \\
\hline & 50 & 195.11 & $23 \times 10^{-3}$ & 0.9954 & 29.74 & 442.24 & 0.0395 & 0.9967 & 1.6622 & 0.994 & 0.1590 \\
\hline & 60 & 197.29 & $21 \times 10^{-3}$ & 0.9990 & 32.32 & 712.14 & 0.0418 & 0.9989 & 1.6921 & 0.995 & 0.1462 \\
\hline \multirow[t]{4}{*}{75} & 30 & 265.76 & $28 \times 10^{-3}$ & 0.9987 & 33.59 & 302.95 & 0.0263 & 0.9984 & 1.5714 & 0.997 & 0.1812 \\
\hline & 40 & 269.83 & $27 \times 10^{-3}$ & 0.9967 & 38.25 & 412.92 & 0.0268 & 0.9967 & 1.6016 & 0.999 & 0.1718 \\
\hline & 50 & 278.59 & $26 \times 10^{-3}$ & 0.9961 & 40.42 & 500.05 & 0.0267 & 0.9983 & 1.6260 & 0.998 & 0.1662 \\
\hline & 60 & 281.20 & $24 \times 10^{-3}$ & 0.9981 & 34.63 & 673.53 & 0.0288 & 0.9943 & 1.6406 & 0.997 & 0.1520 \\
\hline \multirow[t]{4}{*}{100} & 30 & 319.81 & $31 \times 10^{-3}$ & 0.9975 & 34.36 & 200.22 & 0.0197 & 0.9982 & 1.4709 & 0.998 & 0.2079 \\
\hline & 40 & 326.80 & $29 \times 10^{-3}$ & 0.9969 & 38.74 & 273.80 & 0.0202 & 0.9972 & 1.5100 & 0.992 & 0.1946 \\
\hline & 50 & 338.38 & $14 \times 10^{-3}$ & 0.9973 & 39.64 & 267.73 & 0.0193 & 0.9969 & 1.5198 & 0.994 & 0.1973 \\
\hline & 60 & 345.49 & $28 \times 10^{-3}$ & 0.9989 & 44.37 & 382.72 & 0.0200 & 0.9981 & 1.5588 & 0.991 & 0.1830 \\
\hline \multirow[t]{4}{*}{125} & 30 & 364.90 & $31 \times 10^{-3}$ & 0.9928 & 35.93 & 168.18 & 0.0163 & 0.9948 & 1.3953 & 0.992 & 0.2255 \\
\hline & 40 & 377.59 & $32 \times 10^{-3}$ & 0.9941 & 36.36 & 164.50 & 0.0156 & 0.9994 & 1.4028 & 0.991 & 0.2288 \\
\hline & 50 & 391.93 & $20 \times 10^{-3}$ & 0.9948 & 37.38 & 174.85 & 0.0152 & 0.9972 & 1.4219 & 0.992 & 0.2264 \\
\hline & 60 & 397.03 & $31 \times 10^{-3}$ & 0.9959 & 42.08 & 228.70 & 0.0156 & 0.9963 & 1.4589 & 0.991 & 0.2129 \\
\hline
\end{tabular}

Table5. The Kinetic Parameters for the Adsorption of Nickel Ion onto APANC 
From Table 5 it is clear that the reaction is spontaneous in nature as $\Delta \mathrm{G}^{0}$ values are negative at all the temperature studied. Again positive $\Delta \mathrm{H}^{0}$ value confirms that the sorption is endothermic in nature. The positive value of $\Delta \mathrm{S}^{0}$ reflects the affinities of the adsorbents for the $\mathrm{Ni}$ (II). The result as shown in Table 5 indicate that the probability of the $\mathrm{Ni}$ (II) to stick on surface of biomass is very high as $\mathrm{S}^{*}<<$ 1 , these values confirm that, the sorption process is physisorption.

\subsection{Desorption Studies}

Desorption studies help to elucidate the nature of adsorption and recycling of the spent adsorbent and the metal ions. If the adsorbed metal ions can be desorbed using neutral $\mathrm{pH}$ water, then the attachment of the metal ion of the adsorbent is by weak bonds. The effect of various reagents used for desorption studies. The results indicate that hydrochloric acid is a better reagent for desorption, because we could get more than $90 \%$ removal of adsorbed metal ion. The reversibility of adsorbed metal ion in mineral acid or base is in agreement with the $\mathrm{pH}$ dependent results obtained. The desorption of metal ion by mineral acids and alkaline medium indicates that the metal ion was adsorbed onto the APANC through physisorption as well as by chemisorptions mechanisms.

\section{CONCLUSION}

APANC prepared from Pandanus Amaryllifolius Stem (Aavaarai) was found effective in removing nickel ion from aqueous solution. The adsorption is faster and the rate is mainly controlled by intraparticle diffusion. Using the sorption equation obtained from the Langmuir and Freundlich isotherms, it was found that APANC is an effective one for the removal of nickel ion. The equilibrium data conformed well to the Langmuir and BET isotherm models. The temperature variation study showed that the nickel ion adsorption is endothermic and spontaneous with increased randomness at the solid solution interface. Significant effect on adsorption was observed on varying the $\mathrm{pH}$ of the nickel ion solution. $\mathrm{pH}$ dependent results and desorption of metal ion in mineral acid suggest that the adsorption of metal ion on APANC involves chemisorptions as well as physisorption mechanism.

\section{REFERENCES}

[1] Zolfaghari, G., Esmaili-Sari, A., Anbia, M., Younesi, H. and Ghasemian, M.B., A zinc oxidecoated nanoporous carbon adsorbent for lead removal from water: Optimization, equilibrium modeling, and kinetics studies, (2013). International Journal of Environmental Science and Technology, 10 (2), 325-340.

[2] Memarian, R. and Ramamurthy, A.S., Modeling of lead and cadmium uptake by plants in the presence of surfactants, (2013), Environmental Monitoring and Assessment, 185 (3), 2067-2071.

[3] Vijayaraghavan, K. and Joshi, U.M., Chicken Eggshells Remove Pb (II) Ions from Synthetic Wastewater, (2013), Environmental Engineering Science, 30 (2), 67-73.

[4] Shukla, N.B. and Madras, G., Kinetics of adsorption of methylene blue and rhodamine 6G on acrylic acid-based superabsorbents, (2012), Journal of Applied Polymer Science, 126 (2), 463 472 .

[5] Usman, A.R.A., Sallam, A.S., Al-Omran, A., El-Naggar, A.H., Alenazi, K.K.H., Nadeem, M. and Al-Wabel, M.I., Chemically Modified Biochar Produced from Conocarpus Wastes: An Efficient Sorbent for Fe(II) Removal from Acidic Aqueous Solutions, (2013), Adsorption Science \& Technology, 31 (7), 625-640.

[6] Diaz, P.V., Medina, E.C., Nunez, F.U. and Fabila, M.G., Reuse of Citrullus Lanatus Peel As Biosorbent to Remove Aluminum in Aqueous Phase, (2013), Fresenius Environmental Bulletin, 22 (5), 1432-1440.

[7] Bulgariu, L., Lupea, M., Bulgariu, D., Rusu, C. and Macoveanu, M., Equilibrium Study of Pb(Ii) and Cd(Ii) Biosorption from Aqueous Solution on Marine Green Algae Biomass, (2013), Environmental Engineering and Management Journal, 12 (1), 183-190.

[8] Duran-Blanco, J.M., Lopez-Munoz, B.E. and Olguin, M.T., Influence of pH on U(VI) Adsorption using a Thermally-Treated Mg-Al Hydrotalcite and a Natural Zeolite in a Batch System, (2013), Separation Science and Technology, 48 (5), 797-804.

[9] Vistuba, J.P., Nagel-Hassemer, M.E., Lapolli, F.R. and Recio, M.A.L., Simultaneous adsorption of iron and manganese from aqueous solutions employing an adsorbent coal, (2013), Environmental Technology, 34 (2), 275-282. 
[10] Frendlich H, The dye adsorption is losungen (Adsorption in Solution), (1906), Z Phys. Chem.,57, $385-470$.

[11] Taghdiri, M. and Zamani, N., Hexamine adsorption study on activated carbon from aqueous solutions for application in treatment of hexamine industrial wastewater, (2013), International Journal of Environmental Science and Technology, 10 (1), 19-26.

[12] Bulgariu, L., Hlihor, R.M., Bulgariu, D. and Gavrilescu, M., Sorptive Removal of Cadmium (Ii) Ions from Aqueous Solution by Mustard Biomass, (2012), Environmental Engineering and Management Journal, 11 (11), 1969-1976.

[13] Hadi, M., Mckay, G., Samarghandi, M.R., Maleki, A. and Aminabad, M.S., Prediction of optimum adsorption isotherm: comparison of chi-square and Log-likelihood statistics, (2012), Desalination and Water Treatment, 49 (1-3), 81-94.

[14] Langmuir I, The adsorption of gases plane surfaces of glass, mica and platinum, (1918), J. Am. Soc., 579, $1361-1403$.

[15] Hang, X.F., Xu, Y.M., Wang, L., Sun, Y.B., Lin, D.S., Sun, Y., Qin, X. and Wan, Q., Sorption of $\mathrm{Pb} 2+$ on mercapto functionalized sepiolite, (2013), Chemosphere, 90 (2), 548-555.

[16] Zhou, Y.N., Wang, Z., Zhang, Q., Xi, X.J., Zhang, J. and Yang, W.T., Equilibrium and thermodynamic studies on adsorption of BSA using PVDF microfiltration membrane, (2012), Desalination, 307, 61-67.

[17] Khan, A A, Singh, R P. Adsorption thermodynamics of carbofuran on Sn (IV) arsenosilicate in $\mathrm{H}^{+}, \mathrm{Na}^{+}$and $\mathrm{Ca}^{2+}$ forms, (1987), Colloid \& Surfaces (24) $33-42$.

[18] Ghosh, A. and Das Saha, P., Optimization of Ni(II) adsorption by chemically modified fly ash using response surface methodology modeling, (2012), Desalination and Water Treatment, 49 (1-3), 218-226.

[19] Chien S H. and Clayton.W R, Application of Elovich Equation to the kinetics of Phosphate release and sorption on soil, (1980), Soil Sci. Sco. Am, J., 44, 265 - 268.

[20] W. J. Weber and Morris J C., Kinetics of adsorption on Carbon from solution, (1964), J. Sanitary Engg. Div. 90, 79. 